\title{
Ontogenetic growth rate responses of temperate marine copepods to chlorophyll concentration and light
}

\author{
K. Finlay ${ }^{1, *}$, J. C. Roff $^{2}$ \\ ${ }^{1}$ Départment des Sciences Biologiques, Université du Québec à Montréal (UQAM), CP 8888, Succursale Centre Ville, \\ Montréal, Québec H3C 3P8, Canada \\ ${ }^{2}$ Environmental Science, Acadia University, Wolfville, Nova Scotia B4P 2R6, Canada
}

\begin{abstract}
The relationship between growth rate and food concentration often differs between nauplii and copepodites of the same species, but the nature of these relationships varies between systems and species. The artificial cohort method was used to calculate growth rates of Acartia hudsonica and Eurytemora herdmani nauplii and copepodites in Passamaquoddy Bay, the Bay of Fundy, under a natural range of chlorophyll a concentrations and different light regimes. Of 3 predictive maximum growth rate relationships previously published, the Bělehrádek function provided the most precise maximum growth rates, while the others underestimated growth rates of both nauplii and copepodites. No growth rates were correlated with chlorophyll a concentration in any size fraction, but a wide range in growth rates, particularly for the copepodites, was observed. Growth rates of nauplii and copepodites were lower at reduced than at ambient light intensities, but the reason for this is not clear. In general, naupliar growth appears less likely to be food limited than copepodite growth rates. The lack of observed food limitation for the nauplii in this system could be due to (1) nauplii ingesting more food per unit respiration than copepodites, or (2) nauplii not having sufficient lipid reserves and, under food-limiting conditions, rather than responding to food-limiting conditions by lowering growth rates, simply dying. A lower maximum growth rate and a smaller food resource of nauplii compared to copepodites may also explain why nauplii are less susceptible to food limitation in other systems.
\end{abstract}

KEY WORDS: Copepods · Growth rates · Food concentration $\cdot$ Light levels $\cdot$ Nauplii $\cdot$ Copepodites Resale or republication not permitted without written consent of the publisher

\section{INTRODUCTION}

Because of the role of copepods as the dominant trophic link between primary producers and fish in the oceans, much effort has been directed towards the determination of the mechanisms regulating their production. Temperature, body size and food quantity are all known to influence copepod growth rates and therefore production, but only the relationships of temperature and body size with growth rates are currently well described. For example, the Bělehrádek function has been used for decades to describe the relationship between copepod development times and temperature (McLaren 1978, McLaren \& Corkett 1981, McLaren et al. 1988). Davis \& Alatalo (1992), Huntley \& Lopez
(1992) and Kleppel et al. (1996) have all compiled predictive relationships of copepod growth rates with temperature. Similarly, the negative relationship between growth rate and body size has been well described for copepods (Hirst \& Sheader 1997, Gillooly 2000). To date, however, despite a number of studies that have examined the effect of food quantity on copepod growth rates, predictive relationships have not yet been developed.

The relationship between food quantity and growth rates of copepod nauplii is particularly poorly understood. Many studies have focused primarily on the later stages, since nauplii account for roughly only $10 \%$ of total copepod biomass and production (Roff et al. 1995, Hopcroft \& Roff 1998, McKinnon \& Duggan 
2003). However, nauplii are numerically more abundant than the later stages, and have been demonstrated to contribute disproportionately to grazing (Turner \& Roff 1993, Atkinson 1996, Merrell \& Stoecker 1998). Furthermore, naupliar responses to varying food concentration are different from those of the copepodites and adults of the same species. Therefore, an evaluation of the relative responses of nauplii and copepodite growth rates to food concentration is crucial for a full understanding of marine trophodynamics.

The growth rates of nauplii and copepodites, and their responses to both experimental and natural variations in food concentrations are highly variable among studies. The observed growth rates of nauplii are often lower than those of copepodites under similar food climates (Hopcroft \& Roff 1998, Hopcroft et al. 1998, Calbet et al. 2000). Campbell et al. (2001), in contrast, found that the growth rates of the feeding naupliar stages were, on average, higher than the growth rates of copepodites of Calanus finmarchicus. However, a difference between growth rates of nauplii and copepodites does not in itself indicate food limitation. Instead, the response of growth rates to varying food concentrations must be examined in order to assess the extent of food limitation.

Both nauplii and copepodites of several species have exhibited food limited growth rates. Torres \& Escribano (2003) found that nauplii and copepodites of Calanus chilensis exhibited lower growth rates at very low chlorophyll concentrations, and Calbet \& Alcaraz (1997) noted that the growth rates of Acartia grani nauplii were weakly correlated with the chlorophyll concentration in the $<5 \mu \mathrm{m}$ size fraction of the phytoplankton, while copepodites were strongly dependent on the chlorophyll concentration in the $>5 \mu \mathrm{m}$ size fraction. While Hygum et al. (2000) demonstrated that the growth rates of the nauplii of $C$. finmarchicus were reduced at low chlorophyll concentrations, they concluded that these low chlorophyll concentrations are rarely encountered under natural conditions and that nauplii were less likely to experience food-limiting conditions than copepodites. This is supported by observations that growth rates of nauplii saturate at lower experimental food concentrations than those of copepodites (Calbet \& Alcaraz 1997, Campbell et al. 2001, McKinnon \& Duggan 2003). Hopcroft \& Roff (1998) demonstrated that naupliar growth rates of a variety of copepod species in Jamaica were uncoupled from chlorophyll concentration, while the copepodites and adults became progressively food limited as a function of body size under low chlorophyll concentrations. Hart (1990) similarly concluded that naupliar growth rates of a wide range of copepod species were generally more independent of food concentration than those of copepodites. Hirst et al. (2005) demon- strated that the use of the moult rate method to calculate juvenile copepod growth rates can result in erroneous values, but this does not appear to explain the discrepancies, as there are no consistent trends between the methods used and conclusions drawn regarding food limitation. Thus, while there are some exceptions, nauplii (at the very least) exhibit differences in growth rate responses to varying food concentration, and often are considered to be less food limited under natural food conditions than copepodites of the same species.

It is hypothesised that naupliar growth is less likely to be food limited than growth of copepodites and adults if nauplii are feeding on smaller particles (Hopcroft \& Roff 1998, Richardson \& Verheye 1999). Because of the smaller fluctuations in biomass of smaller particles (Sheldon et al. 1972, Hopcroft \& Roff 1990) and the greater assimilation efficiencies of nauplii feeding on them (Conover 1966, Reinfelder \& Fisher 1991, Besiktepe \& Dam 2002), smaller particles may provide a more stable and energetically rich food resource than larger particles. Therefore, if nauplii do exploit smaller food resources than the later stages, they may have access to a more constant and adequate food supply.

All stages of copepods have been demonstrated to feed on many different types of food, including bacterioplankton (Turner \& Tester 1992, Roff et al. 1995), ciliates and flagellates (Stoecker \& Egloff 1987, Turner et al. 2001), and algae (Uitto 1996, Paffenhöfer 1998). However, experiments on the copepods in our study system failed to find differences between stages in the lower size limit of food consumed (Finlay 2004), and both nauplii and copepodites were demonstrated to feed preferentially on autotrophs over heterotrophs (Finlay \& Roff 2004). Thus, it is of interest to determine whether the copepod developmental stages in this system similarly demonstrate differences in food limitation, in the absence of obvious food preference differences between stages.

This study had 2 objectives: (1) to explore how growth rates of nauplii in a temperate estuary respond to the varying chlorophyll a concentrations in the different size fractions of the phytoplankton, and to compare naupliar and copepodite responses, and (2) to compare observed growth rates to published maximum growth rates, to determine under what natural conditions temperate nauplii may experience food limited growth.

\section{MATERIALS AND METHODS}

Field sampling. All experiments were conducted at the Huntsman Marine Science Centre (HMSC) in St. Andrews, New Brunswick, Canada, during the sum- 
mer of 2000, and all experimental animals were taken from Passamaquoddy Bay in the Bay of Fundy.

We sampled 1 site, approximately $2 \mathrm{~km}$ south of the HMSC, on a weekly basis for temperature and salinity using a YSI sonde (Model 30 salinity-conductivity-temperature meter, Yellow Springs Instrument Co.) at $1 \mathrm{~m}$ intervals down to $15 \mathrm{~m}$. On each date, 31 Niskin samples were taken at $3 \mathrm{~m}$ depth and analysed fluorometrically for chlorophyll $a$, following Strickland \& Parsons (1968). We serially size-fractionated 3 replicate measures of $500 \mathrm{ml}$ each and analysed these for chlorophyll a concentration in the microplankton $(>20 \mu \mathrm{m}$, collected on $20 \mu \mathrm{m}$ Nitex mesh filters), nanoplankton ( 2 to $20 \mu \mathrm{m}$, collected on Whatman GF-D filters) and picoplankton ( 0.7 to $2.0 \mu \mathrm{m}$, collected on Whatman GFF filters).

Artificial cohort method for determining growth rate. We performed 4 experiments between 21 July and 23 August 2000. The artificial cohort method of Kimmerer \& McKinnon (1987) was used to determine growth rates of copepod nauplii and copepodites incubated under different food conditions. Experiments were set up by pumping water directly from the bay at approximately $1 \mathrm{~m}$ depth through a $100 \mu \mathrm{m}$ Nitex mesh into $20 \mathrm{l}$ polyethylene carboys $(\mathrm{n}=18)$ to isolate the nauplii and their food and to eliminate predators. It was anticipated that the reduction of food resources by copepod grazing would be negligible, since copepod abundance was reduced considerably from natural levels. Filtering through $100 \mu \mathrm{m}$ mesh effectively left only Stage NI and some Stage NII of the study species, with a maximum density of about 25 individuals $\mathrm{l}^{-1}$. Even in the event of $100 \%$ survival throughout the experiments, the copepodites present at the end of the experiments would only be clearing a maximum of $250 \mathrm{ml}$ of food from each $1 \mathrm{l}$ water each day (calculated using Peters \& Downing 1984's relationship for clearance rate and body size). This would not be enough to reduce phytoplankton concentrations, assuming a doubling rate of approximately $1 \mathrm{~d}^{-1}$. The carboys were incubated in an outdoor water bath with a flowthrough of bay water, which kept them at ambient bay temperature, which was continuously monitored with 4 TidbiT thermistors (Onset Computers).

We sampled 2 of the carboys immediately for initial conditions. Of the remaining 16 carboys, 8 were left in ambient sunlight (light treatment), to increase the chlorophyll concentration, while the other 8 were covered and left in approximately $1 \%$ incident sunlight (shaded treatment) under natural photoperiod to maintain ambient chlorophyll levels. Every 2 or $3 \mathrm{~d}(3 \mathrm{~d}$ intervals were used for Expt 1 and the first half of Expt 2, and $2 \mathrm{~d}$ intervals were used for the remainder of Expt 2, and for Expts 3 and 4, resulting in total incubation times of 12, 9, 8 and $8 d$, respectively for each experiment) 2 carboys from each treatment were removed from the water bath and sampled. For each carboy, temperature and salinity were measured, and 3 replicate samples were size-fractionated for chlorophyll a concentration (used here as an index of phytoplankton biomass) as described in the foregoing subsection. Phytoplankton and heterotrophic protist samples were also taken from each carboy by preserving $250 \mathrm{ml}$ of water in $10 \%$ Lugol's solution. The copepods present in the remaining water (approximately 18 l) were collected on $20 \mu \mathrm{m}$ Nitex mesh, stained with a vital stain (neutral red, Omori \& Ikeda 1984), and preserved in $4 \%$ formalin. Each time a set of carboys was processed, the remaining carboys in the water bath were inverted several times to resuspend any sedimented food particles. Chlorophyll analyses before and after mixing verified that this process was sufficient to prevent excessive sedimentation.

It was believed that due to light limitation of the phytoplankton in this system, differences in light climate (the light and shade treatments) would force differential phytoplankton growth. Initial experiments had indicated that the phytoplankton in this system were also nutrient limited, but addition of nutrients would have made it difficult to prevent uncontrolled phytoplankton blooms. Furthermore, the addition of nutrients is known to preferentially increase the concentration of larger autotrophic cells and would not have increased the food concentration for all copepods systematically. Thus, we opted not to control phytoplankton concentration through nutrient addition.

Differences in light levels, however, could also affect the following parameters of the potential food resources: (1) chlorophyll a concentration per cell (phytoplankton in low light are known to increase their chlorophyll content per cell); (2) percentage of diatoms present (this may be important, as there is evidence that high concentrations of some diatoms can be toxic to copepods, Ianora et al. 2003); (3) proportion of heterotrophs in the light and shade treatments. In order to investigate these potential differences, autotrophic and heterotrophic organisms in the Lugol preserved samples were identified to the lowest possible taxonomic level, enumerated, and sized using the Utermöhl technique (Utermöhl 1958). Cells were also categorised as autotrophic or heterotrophic based on taxonomy; mixotrophs were included in the autotrophic category. The approximate biovolume of each cell in the nanoplankton and microplankton was calculated using cell measurements, and the total biovolume was calculated by multiplying this by abundance. These biovolume estimates were then used together with measurements of chlorophyll a concentration of each size fraction to obtain an estimate of 
biovolume:chlorophyll ratio in the initial carboys and the light and shade treatments. The proportion of total biovolume comprised by diatoms and heterotrophs was also calculated for these treatments. Student's $t$ tests with a Bonferroni correction were used to determine the differences between treatments and time. These analyses were only done for the second experiment, since this experiment had the greatest difference in chlorophyll a concentration between light and shade treatments, and the greatest difference in growth rates between the 2 treatments. Therefore, if the light/shade treatments had any effect on biovolume:chlorophyll a ratio, diatom, or heterotroph composition, it should have been most noticeable in the carboys of this experiment.

After approximately $6 \mathrm{~d}$ incubation (the exact time varied between experiments), the majority of nauplii had matured into copepodites. For each species in each treatment and each experiment, we calculated the growth rate for nauplii and that for copepodites. Growth rates were calculated as the change in weight between 2 successive dates when the majority of copepods were at the same development stage. This resulted in the calculation of naupliar growth rates after 4 or $6 \mathrm{~d}$ incubation, and the calculation of copepodite growth rates after 8 or $12 \mathrm{~d}$, depending on the size and stages of the individuals present in the various carboys. The time periods over which growth was calculated are indicated in Fig. 2. In order to calculate growth rates of the copepods, the cephalothorax length of 100 copepods, identified to species, were digitised using the ZoopBiom program of Roff \& Hopcroft (1986). The length-weight regression from Middlebrook \& Roff (1986) was used for Eurytemora herdmani, while that of Landry (1978) was used for Acartia hudsonica. Middlebrook \& Roff (1986) noted that the regression in Landry (1978) was not significantly different from their calculated length-weight regression for $A$. hudsonica copepodites in Passmaquoddy Bay. Although Middlebrook \& Roff (1986) only reported length-weight regressions for $E$. herdmani copepodites, this regression was extrapolated to include naupliar lengths for our calculations. For most species, length-weight regressions between nauplii and copepodites have similar slopes, but the relationships for copepodites have lower $y$-intercepts. Thus, the use of this regression equation will underestimate E. herdmani naupliar weight, but the growth rates should be accurate. Growth rates $(\mathrm{g})$ were then calculated using the equation $g=1 / t \times \ln W_{t} / W_{0}$, where $t=$ time between successive dates, and $W_{0}$ and $W_{t}$ represent initial and final weights, respectively. The relationship between growth rate and chlorophyll a concentration for each size fraction (averaged for each treatment at the beginning of each time period over which growth rate was calculated) was examined using linear regression.

The use of published length-weight regressions to determine the weight of the copepods for the growth rate calculations requires some caution. Rey et al. (2001) noted that Calanus helgolandicus nauplii reared under low food conditions exhibited lower weights at a given length than those raised under high food conditions. Thus, the use of a general length-weight regression to represent all copepods in all food treatments may not accurately represent the actual weight of the copepods in the different treatments. However, in order to account for this potential variability, it would have been necessary to weigh every individual copepod in the experiments in order to examine differences due to varying food concentration. Since the measurement of copepod mass, particularly for nauplii, is still not routine and simple (most reports of naupliar weights require the measurement of 30 to 50 individuals in order to obtain sufficient mass), this was simply not logistically possible for this experiment. Furthermore, we argue that any differences in weight of the copepods in our study system would not be as great as those in Calanus helgolandicus, since Acartia hudsonica and Eurytemora herdmani are far smaller than C. helgolandicus, and are much less likely to respond to varying food concentration by altering their lipid reserves (Båmstedt 1986). Nevertheless, we directly tested for weight differences among the copepods in these experiments by measuring the carbon content of nauplii and copepodites of comparable size under high and low food treatments. Using the wet oxidation method (Strickland \& Parsons 1968), modified to measure nanogram quantities of carbon in biological materials (Stafford, Roff, and Robertson unpubl. data), 20 nauplii and copepodites from the experiments that differed most in food quantity were measured, and no significant differences in weight were detected (data not shown).

Comparison of observed to predicted maximal growth rates. Predicted growth rates were calculated using the expressions of Huntley \& Lopez (1992) and Kleppel et al. (1996). Huntley \& Lopez (1992) compiled published values of field-derived growth rates across a range of temperatures and productivities to obtain empirical, temperature related growth rate expressions. Kleppel et al. (1996) subsequently modified this analysis to examine only the highest rates of growth, claiming that food limitation probably lowered the observed growth rate values at most temperatures. Huntley \& Lopez (1992) give a $95 \%$ confidence interval for the growth rate of copepods at a given temperature $(T)$. Huntley \& Lopez' (1992) equations are: lower $95 \%: g=0.0415 \mathrm{e}^{0.105 T}$; upper 95\%: $g=0.0477 \mathrm{e}^{0.116 T}$. 
Therefore, at an average temperature of $13.8^{\circ} \mathrm{C}$ (the average temperature over all 4 experiments), the expected maximum growth rates fall between 0.171 and $0.228 \mathrm{~d}^{-1}$.

The Kleppel et al. (1996) equation is $\mathrm{g}=0.064 \mathrm{e}^{0.102 T}$, which yields a growth rate estimate of $0.254 \mathrm{~d}^{-1}$ at $13.8^{\circ} \mathrm{C}$.

A third estimate of maximum growth rate was taken from the Bělehrádek function of development time versus temperature for Eurytemora herdmani in McLaren \& Corkett (1981) and Acartia clausi (=A. hudsonica) in McLaren et al. (1969). These sources provide separate development times for eggs, Stages NI to CI, and total generation time. Assuming equiproportional development, these relationships were recalculated to obtain development times from Stages NI to NVI and from CI to adult. Using the average lengths of each stage from Murphey \& Cohen (1979) and converting them to weights using the length-weight regressions noted above, these development times were recalculated to given another estimate of growth rate. Thus, in contrast to the predicted maximum growth rate values presented by Huntley \& Lopez (1992) and Kleppel et al. (1996), who used average growth rates across species and stages, the Bělehrádek function provided species and stage specific development times.

\section{RESULTS}

\section{Natural vs. experimental conditions}

The temperature of the bay only varied between 13.0 and $14.2^{\circ} \mathrm{C}$ during the experimental period, and the temperature of the incubation water bath always remained within these values. There was no observable difference in water temperature between the shaded and unshaded portions of the outdoor water bath. The light levels, as well as oxygen and salinity also remained comparable between the light treatments of the experiments and the natural fluctuations in the bay. The light levels in the shaded half of the water bath were always at least $1 \%$ of incident light, and also showed a natural photoperiod.

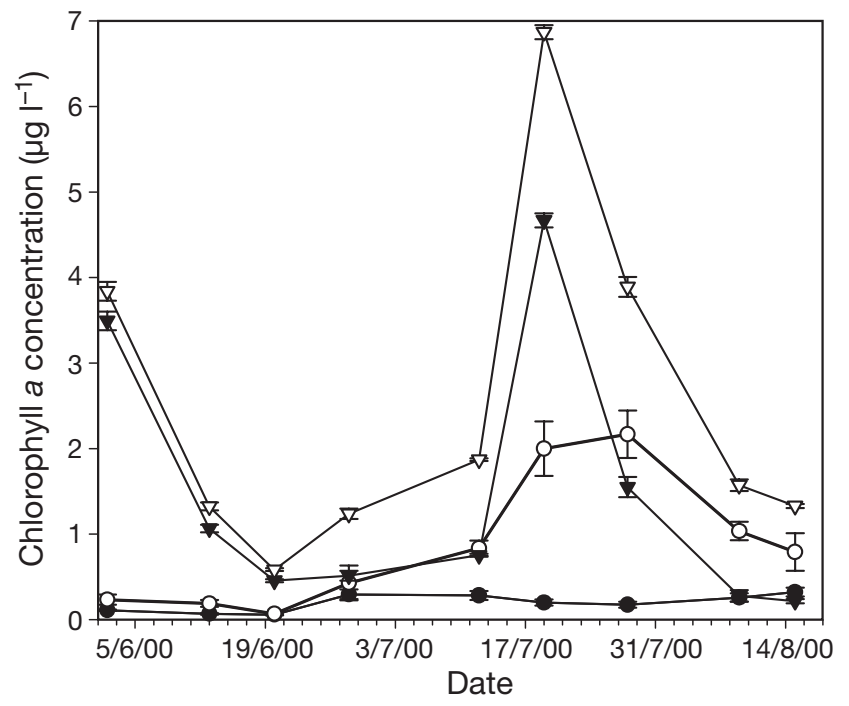

Fig. 1. Fluctuations (means $\pm \mathrm{SE} ; \mathrm{n}=3$ ) in chlorophyll a concentration in Passamaquoddy Bay, New Brunswick, during summer 2000. (•) Picoplankton $(0.7$ to $2.0 \mu \mathrm{m})$; (O) nanoplankon $(2.0 \text { to } 20 \mu \mathrm{m})_{i}(\mathbf{v})$ microplankton $(>20 \mu \mathrm{m})_{i}(\nabla)$ total chlorophyll concentration (sum of the 3 size fractions)

The concentration of the smallest size fraction of chlorophyll a (the picoplankton) varied much less than that of the nano- and microplankton at the monitoring site in the bay (Fig. 1, Table 1). This was not the case, however, in the experimental containers, where the picoplankton experienced the greatest variability of all phytoplankton size fractions. Although the mean chlorophyll a concentrations in the experiments were within the natural range, the extreme values of the largest and smallest size fractions exceeded those observed in the bay (Table 1).

The majority of all copepods ( $90 \%)$ during the experimental period consisted of Acartia hudsonica and Eurytemora herdmani. Other observed species included Oithona similis, Tortanus discaudatus, Temora longicornis and Centropages typicus, which together constituted only 5 to $10 \%$ of the total copepod abundance; these were not included in the analyses.

Table 1. Minimum, maximum, mean $(+\mathrm{SD})$ and ratio of maximum to minimum chlorophyll a concentrations $\left(\mu \mathrm{g} \mathrm{l}^{-1}\right)$ in natural (monitoring site in Passamaquoddy Bay, New Brunswick, $\mathrm{n}=9$ for each size fraction) and experimental (carboys used in growth rate calculations of artificial cohorts, $\mathrm{n}=16$ ) water samples

\begin{tabular}{|c|c|c|c|c|c|c|}
\hline \multirow[t]{2}{*}{ Species } & \multicolumn{2}{|c|}{ Picoplankton } & \multicolumn{2}{|c|}{ Nanoplankton } & \multicolumn{2}{|c|}{ Microplankton } \\
\hline & Natural & Experimental & Natural & Experimental & Natural & Experimental \\
\hline Minimum $\left(\mu g \mathrm{l}^{-1}\right)$ & 0.059 & 0.021 & 0.069 & 0.127 & 0.216 & 0.098 \\
\hline Maximum $\left(\mu g \mathrm{l}^{-1}\right)$ & 0.322 & 0.824 & 2.17 & 2.1 & 4.67 & 3.18 \\
\hline Mean $\left(\mu g ~^{-1}\right)$ & $0.196(0.100)$ & $0.153(0.207)$ & $0.867(0.766)$ & 0.867 (0.686) & $1.443(1.570)$ & 1.017 (0.99) \\
\hline Max:min & 5.5 & 39.2 & 31.5 & 16.5 & 21.6 & 32.5 \\
\hline
\end{tabular}



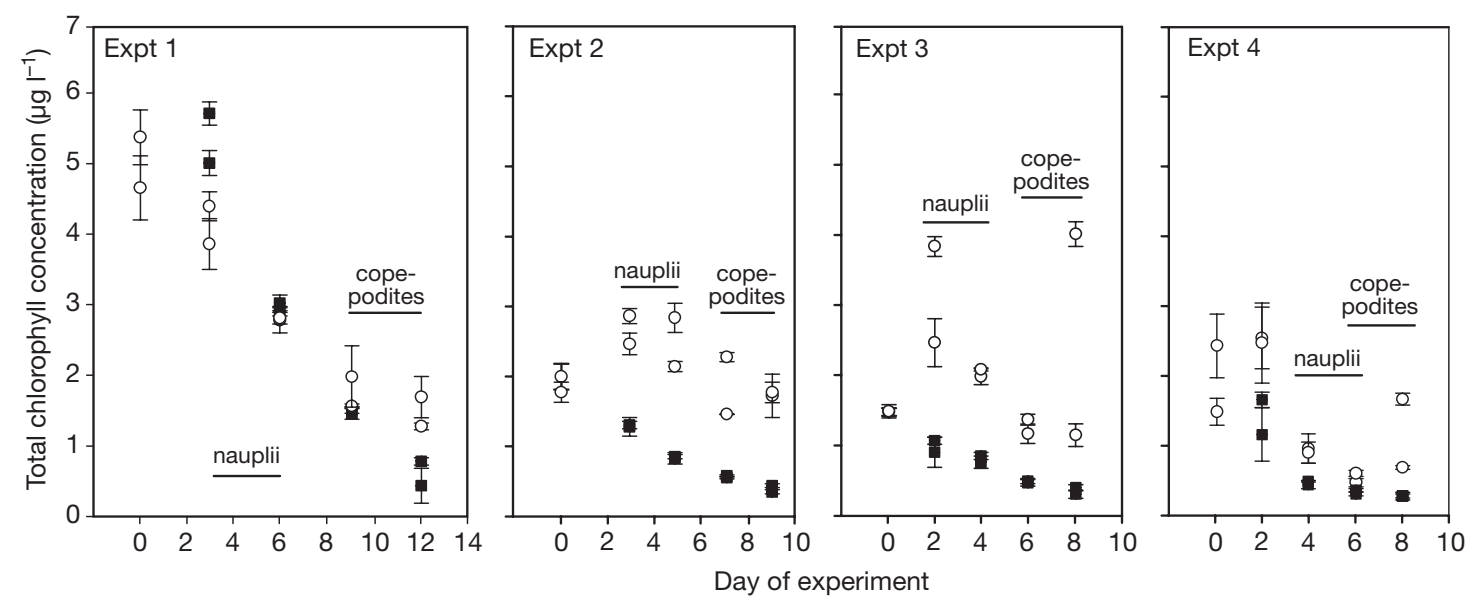

Fig. 2. Total chlorophyll a concentration (means $\pm \mathrm{SE} ; \mathrm{n}=3$ ) in Expts 1 to 4 . (O) Concentration in carboys in light treatments; (घ) concentration in shaded carboys. Horizontal bars span amount of time over which growth rates were calculated for nauplii and copepodites

\section{Artificial cohort method}

The mortality of copepods was negligible $(<5 \%)$ in all experiments, and no dead copepods (i.e. unstained with the vital stain) were included in the analyses. During the first 3 experiments, the Acartia hudsonica and Eurytemora herdmani copepods were approximately equal in abundance. By the final experiment, however, E. herdmani greatly outnumbered the A. hudsonica copepods, and therefore growth rates of only E. herdmani were calculated for this experiment. Thus, a total of 8 growth rates were calculated for both $E$. herdmani nauplii and copepodites (4 experiments with both light and shade treatments) and 6 for A. hudsonica nauplii and copepodites.

Chlorophyll a concentrations in the carboys varied considerably amongst the different experiments (Fig. 2). In general, the chlorophyll concentration was higher in the light treatments within an experiment, but the chlorophyll a concentrations between experiments varied such that the shaded carboys often had higher chlorophyll concentration than the carboys receiving light (Figs. $3 \& 4$ ). Also, the copepodites never experienced chlorophyll concentrations at the high values observed in situ, while the maximum chlorophyll concentration experienced by the nauplii was much closer to the natural maximum (compare the $x$-axis values of Figs. $3 \& 4$ with the maximum values of natural chlorophyll in Table 1). The minimum chlorophyll values for both nauplii and copepodites, however, were similar to the minimum natural levels.

The average growth rates of the copepods in the light treatments did not differ significantly between nauplii and copepodites of the same species. Eurytemora herdmani generally had higher growth rates than Acartia hudsonica (Table 2), but these differences were not significant (Student's $t$-test, $\mathrm{p}>0.05$ ).
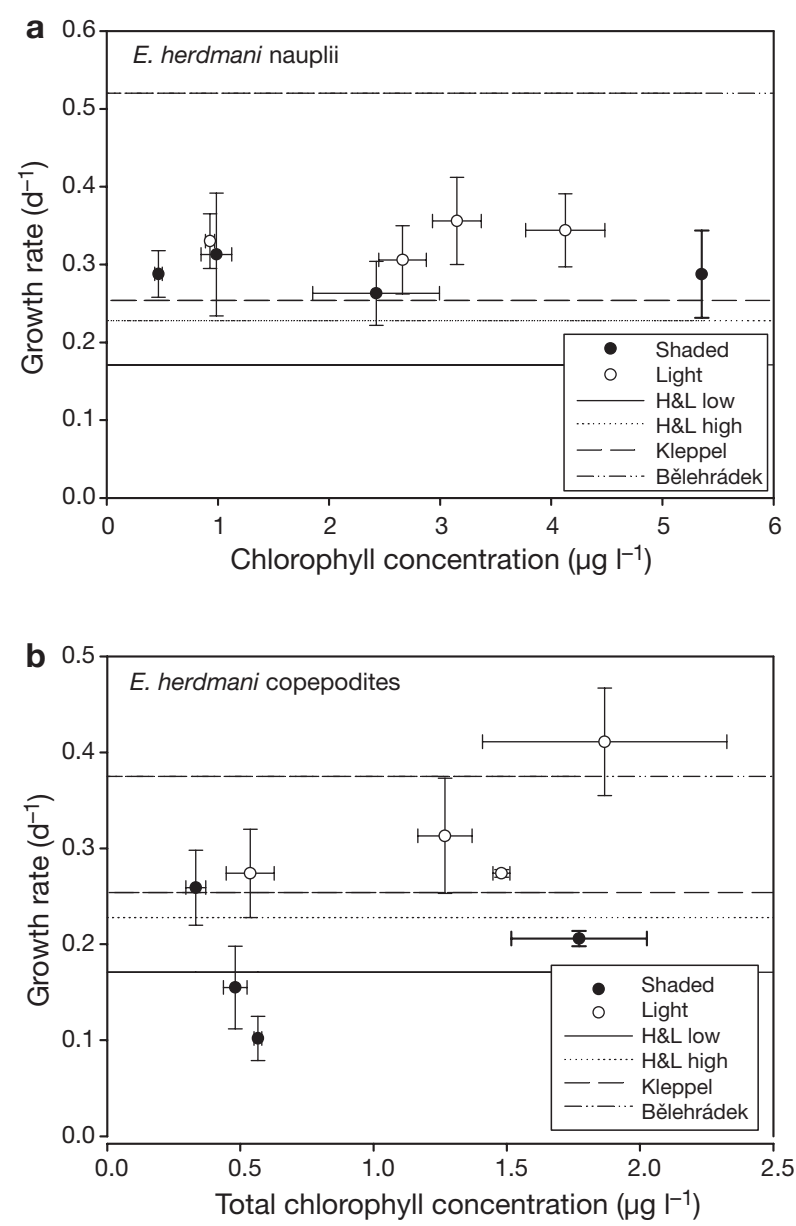

Fig. 3. Eurytemora herdmani. Growth rates (means $\pm \mathrm{SE}$; $\mathrm{n}=2$ ) of (a) nauplii and (b) copepodites vs. total chlorophyll $a$ concentration. ( $(\mathrm{O})$ Growth rates in light treatment; $(\bullet)$ growth rates in shaded treatment. Previously published maximum growth rates are also presented as horizontal lines (H\&L low and high equations from Huntley \& Lopez 1992; Kleppel et al. 1996; and Bělehrádek from McLaren \& Corkett 1981 and McLaren et al. 1969). 

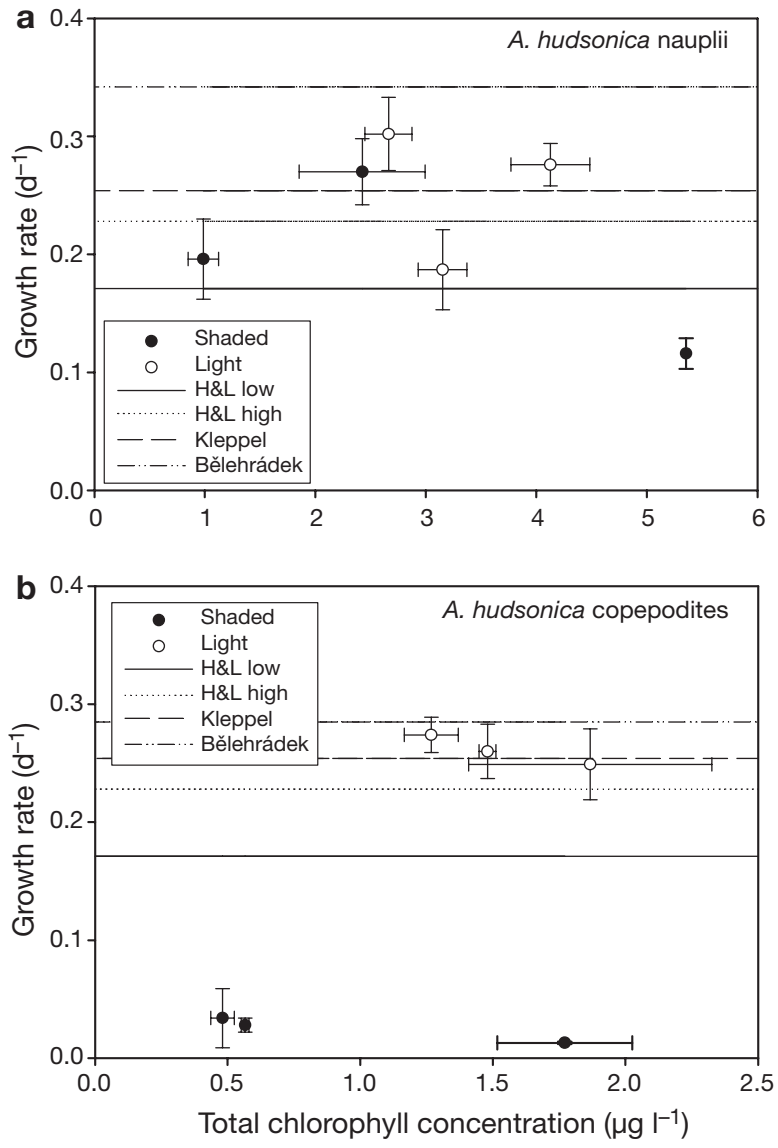

Fig. 4. Acartia hudsonica. Growth rates of (a) nauplii and (b) copepodites vs. total chlorophyll a concentration. Symbols and lines as in Fig. 3

There were no significant relationships between growth rate and weight or chlorophyll concentration in any size fraction for any species or stage; thus, detailed figures on these aspects are not presented here. Nevertheless, a wide range of growth rates was observed, particularly for the copepodites. The major differences in growth were between those copepods in the light vs. shade treatments, rather than those with high or low food concentrations, as evidenced by the growth rate vs. total chlorophyll concentration illustrated in Figs. 3 $\& 4$. The average growth rates of Acartia hudsonica and Eurytemora herdmani copepodites and E. herdmani nauplii were significantly lower in the shade treatments than in the light (all Student's $t$-tests, $\mathrm{p}<0.05$ ). Growth rates of $A$. hudsonica nauplii did not, however, differ significantly between the different light conditions.

The comparison of food conditions between light and shade treatments in the second experiment did not yield significant differences for any index measured. The biovolume:chlorophyll a ratio ranged from $7 \times 10^{4}$ to $22.5 \times 10^{4} \mu \mathrm{m}^{3}: \mu \mathrm{g}$ chlorophyll $a$, and no significant or systematic differences were found between any of the carboys over time within a treatment, or between carboys in the light and shade treatments (all Student's $t$-tests, $\mathrm{p}>0.10$ ). Similarly, there were no significant differences in the percentage of diatom biovolume, which ranged from 2.0 to $12 \%$, nor for the percentage of heterotrophic biovolume, which ranged from 2.5 to $15.2 \%$ across all carboys.

\section{Comparison of observed with predicted maximal growth rates}

The average growth rates of all Eurytermora herdmani nauplii were higher than the predicted maximum values of Huntley \& Lopez (1992) and Kleppel et al. (1996), but lower than that predicted by the Bělehrádek function (Fig. 3a). The average growth rates of $E$. herdmani copepodites in the light treatment were similarly higher than the maximum predicted rates except for the Bělehrádek function (Fig. 3b). The E. herdmani copepodites in the shaded treatment, on the other hand, fell below several, if not all, the predicted maxi-

Table 2. Acartia hudsonica and Eurytemora herdmani. Predicted and observed growth rates of nauplii and copepodites. Predicted development times from McLaren et al. (1969) and McLaren \& Corkett (1981) at $13.8^{\circ} \mathrm{C}_{\text {; }}$ lengths of each stage from Murphey \& Cohen (1979); weights derived from length-weight regressions of Landry (1978) and Middlebrook \& Roff (1986). Growth increments presented as $\ln \left(W_{t} / W_{0}\right)$, where $W_{t}=$ final weight and $W_{0}=$ initial weight. Observed growth rates are average (SD) of rates in light treatments ( $\mathrm{n}=3$ for $A$. hudsonica; $\mathrm{n}=4$ for E. herdmani)

\begin{tabular}{|c|c|c|c|c|c|c|c|c|}
\hline \multirow[t]{2}{*}{ Species } & \multirow{2}{*}{$\begin{array}{c}\text { Development } \\
\text { time } \\
\text { (d) }\end{array}$} & \multicolumn{2}{|c|}{ First stage (CI or NI) } & \multicolumn{2}{|c|}{ Last stage (CVI or NVI) } & \multirow{2}{*}{$\begin{array}{l}\text { Growth } \\
\text { increment } \\
\ln \left(W_{t} / W_{0}\right)\end{array}$} & \multicolumn{2}{|c|}{ Growth rate $\left(\mathrm{d}^{-1}\right)$} \\
\hline & & $\begin{array}{l}\text { Length } \\
(\mu \mathrm{m})\end{array}$ & $\begin{array}{l}\text { Weight } \\
(\mu g)\end{array}$ & $\begin{array}{c}\text { Length } \\
(\mu \mathrm{m})\end{array}$ & $\begin{array}{c}\text { Weight } \\
(\mu g)\end{array}$ & & Predicted & Observed \\
\hline \multicolumn{9}{|l|}{ E. herdmani } \\
\hline nauplii & 6.34 & 110 & 0.027 & 370 & 0.775 & 3.36 & 0.529 & $0.334(0.021)$ \\
\hline copepodites & 6.70 & 364 & 0.948 & 850 & 11.67 & 2.51 & 0.375 & $0.318(0.064)$ \\
\hline \multicolumn{9}{|l|}{ A. hudsonica } \\
\hline nauplii & 8.26 & 120 & 0.033 & 280 & 0.558 & 2.83 & 0.342 & $0.255(0.060)$ \\
\hline copepodites & 9.3 & 335 & 0.440 & 890 & 6.22 & 2.65 & 0.285 & $0.261(0.125)$ \\
\hline
\end{tabular}


mum values. The only growth rate value for Acartia hudsonica nauplii that fell below all maximum predictions was in the shaded treatment (Fig. 4a). Finally, similar to E. herdmani copepodites, the growth rates of A. hudsonica copepodites in the light treatment were all above Huntley \& Lopez' (1992) predicted values, but all growth rates for the shaded carboys fell below all predicted maximum values (Fig. $4 \mathrm{~b}$ ). In general, the growth rates of the copepodites in the light treatments did not vary greatly, despite the range of chlorophyll concentrations in the different carboys.

\section{DISCUSSION}

\section{Variations in observed growth rates}

The goal of this study was to examine the differences in growth rate responses of nauplii and copepodites to varying chlorophyll concentrations in a temperate estuary and to compare observed growth rates to 3 different predicted values. The growth rates of neither the nauplii nor the copepodites could be correlated with the chlorophyll concentration of any size fraction, yet there was a wide range of observed growth rates, particularly for the copepodites. Many observed growth rates were higher than the predicted maximum growth rates of Huntley \& Lopez (1992) and Kleppel et al. (1996), while none exceeded those predicted by the Bělehrádek function. The values used for the relationship derived by Huntley \& Lopez (1992) and Kleppel et al. (1996) were from field estimates, which may have included food limited values, while those for the Bělehrádek function were all derived from laboratory based experiments, with ample food provided (McLaren et al. 1969, McLaren \& Corkett 1981). The calculations converting the Bělehrádek function to predicted growth rates required the use of a few approximations (lengthweight regressions and estimates of lengths of each stage) and thus should be interpreted with some caution, but our results indicate that of the 3 functions, the Bělehrádek function may provide the most accurate estimates of maximum growth rates.

The most notable results observed here were not the responses of growth rates to chlorophyll concentration, but the effect of the light and shaded treatments on growth. Not only were the mean growth rates of the copepodites of both species and of Eurytemora herdmani nauplii significantly lower in the shaded treatments, but the growth rates of the copepodites in the shade also tended to fall further below the predicted maximum growth rates, indicating that growth was limited in these treatments. It thus appears that some difference between the light and shade treatments caused some reduction in feeding activity that (1) acted more strongly on the copepodites, and (2) could not be accounted for by chlorophyll a concentration alone.

The possibility that variations in chlorophyll a concentration per cell in the light and shade treatments were confounding our results has been discounted, as no significant differences were found between treatments or over time. There is considerable discussion in the literature regarding the potential toxicity of diatoms in the copepod diet (Paffenhöfer 2002, Ianora et al. 2003), but there is little evidence of this with a mixed diet (Irigoien et al. 2002), and the light and shade treatments did not significantly alter the percentage of diatoms present in the experiments. In addition, there was no evidence that the light and shade treatments affected the proportion of heterotrophs.

It is also possible that the different light treatments caused some difference in food quality, resulting in differences in growth of the copepods in the light vs. shade treatments. Higher $\mathrm{N}: \mathrm{C}$ ratios in phytoplankton food have been demonstrated to increase growth rates (Touratier et al. 1999, Jones et al. 2002); however, reduced light would be more likely to increase the $\mathrm{N}: \mathrm{C}$ ratio (Hessen et al. 2002), and thus the food particles in the shade treatment would be of higher quality than those in the light treatment. Micronutrient composition or phase of growth of phytoplankton may also have been affected by light intensity, but these characteristics were not quantified in our experiments, nor are the relationships between these quality measures and light intensity well known at present. Thus, it is possible that the copepods in our experiments may have experienced food limited growth in terms of quality rather than quantity, but the underlying mechanisms of this are not yet understood.

That the nauplii were predominant at the beginning of the experiments, while copepodites were dominant at the end, also does not explain the differences in growth in the light and shaded treatments. While it is possible that the differences in the food environment were more apparent later in the experiments, additional experiments on the copepods in this system negate this possibility. Similar artificial cohort experiments were performed in 2002, but in those experiments, all carboys were incubated under shade conditions and nauplii and copepodites were incubated separately for a total of $6 \mathrm{~d}$. The results revealed low growth rates for Acartia hudsonica copepodites $\left(0.13^{-1}, \mathrm{SD}=0.01\right)$, while the nauplii reached much higher growth rates $\left(0.26 \mathrm{~d}^{-1}, \mathrm{SD}=0.03\right.$, Student's $t$-test, $\mathrm{p}=0.005, \mathrm{n}=8$ ) (Finlay 2004). This suggests that the copepodites were more sensitive to the shade treatment than were the nauplii.

Another potential explanation is that there was a behavioural feeding depression of the copepods in the shade treatments. Some studies have indicated that 
copepods feed more at night (Dale \& Kaartvedt 2000, Huggett \& Richardson 2000), while others have demonstrated increased feeding at dawn and dusk (Head \& Harris 1987). All copepods in our experiments experienced reduced light with a natural day-night periodicity, but the shade treatment may have inhibited feeding cues. Furthermore, these light cues may be more important for copepodite feeding than for nauplii feeding, since copepodites undergo greater diel vertical migration, which probably results in greater variations in their feeding rates compared to nauplii.

Although effects of light intensity on feeding rates have been reported, light effects on growth rates have apparently not been examined before. In fact, light intensities are rarely if ever adequately reported in zooplankton growth experiments, and we suspect that this may be an important contributory factor to the variability and discrepancies in reported values. The lower growth rates of copepods in experiments in the dark may be an artefact of experimental conditions, or may be a real phenomenon, that also occurs in nature. If it is an artefact, then it is still of major significance, since the effects of light on estimates of growth rates have been unappreciated thus far, and we do not know the critical light intensities or fluctuations that may affect experimental measurements. If the relationship between light intensity and growth rate is real, how may it apply under natural conditions? It seems that there may be more subtle interactions of light climate, water column turbulence, feeding regime and even species-specific effects on growth rates of copepods than we have heretofore realised, and whose ecological and adaptive significance is far from clear.

\section{Food limitation of nauplii and copepodites}

The results herein suggest that either the nauplii were less food limited in terms of food quality, or their feeding behaviour was less influenced by the shade treatment than that of the copepodites. Whichever the case may be, there was no evidence that the nauplii in our study system were food limited.

Based on the allometric relationship between body size and metabolism (Peters 1983) and the Ivlev function that states that ingestion must equal the sum of growth, respiration, and egestion, it follows that nauplii will require more food per unit weight than copepodites. Paradoxically, however, nauplii are less often demonstrated to experience food limited growth. While some studies have demonstrated that nauplii can exhibit food limited growth (Calbet \& Alcaraz 1997, Campbell et al. 2001), several have demonstrated that nauplii are less likely to be food limited than the later stages (Hart 1990, Hopcroft \& Roff 1998, Hopcroft et al. 1998). Furthermore, in the present study we found very little variation in growth rates of nauplii despite a wide range of chlorophyll concentrations, while copepodite growth was highly variable. Thus the question arises, as to how nauplii overcome their increased food requirements to the extent that they are rarely food limited.

One trend in the results of Hopcroft \& Roff (1998), Hopcroft et al. (1998) and Calbet et al. (2000) is that the naupliar growth rates, on average, tended to be lower than those of the copepodites, which would serve to further lower the food requirements of nauplii relative to that of copepodites. Our results here, however, indicated no significant differences between naupliar and copepodite growth rates, suggesting that there may be alternate explanations. Other authors have suggested that the smaller food resources of copepod nauplii could explain their relative resistance to food limitation (Hopcroft \& Roff 1998, Richardson \& Verheye 1999), but this does not appear to be an adequate explanation for our results, as previous studies have failed to find significant differences in food size or type (Finlay \& Roff 2004).

It also appears, however, that simply a lower total food requirement may play a role. For example, we found Acartia hudsonica nauplii and copepodites had average growth rates of 0.255 and $0.261 \mathrm{~d}^{-1}$, respectively (average rates in our light treatments). The corresponding metabolic rates for nauplii and copepodites at $13.8^{\circ} \mathrm{C}$ are 0.029 and $0.107 \mu \mathrm{g} \mathrm{C} \mathrm{d}^{-1}$, respectively, using the relationship of metabolic rate vs. size and temperature of Mauchline (1998). Assuming an assimilation efficiency of 0.4 , in these experiments this yields daily required ingestion rates of 0.143 and $0.643 \mu \mathrm{g} \mathrm{C} \mathrm{d}^{-1}$ for A. hudsonica nauplii and copepodites, respectively.

Similarly, the clearance rates for these 2 copepod sizes can be approximated using the relationship of Peters \& Downing (1984), which yields clearance rates of $2.97 \mathrm{ml} \mathrm{d}^{-1}$ for the nauplii and $9.98 \mathrm{ml} \mathrm{d}^{-1}$ for the copepodites. While these are admittedly approximations, they do reflect observed clearance rates of similar-sized nauplii and copepodites of Acartia spp. (Berggreen et al. 1988). Assuming a carbon to chlorophyll a ratio of $50: 1$, the nauplii in our experiments would obtain maximum growth rates at a chlorophyll a concentration of $0.96 \mu \mathrm{g}$ chlorophyll $\mathrm{l}^{-1}$, while the copepodites would only reach maximum growth rates at chlorophyll concentrations $>1.29 \mu \mathrm{g}$ chlorophyll $\mathrm{l}^{-1}$. These calculations indicate that even if the different stages are feeding on the same food resources, nauplii can reach maximum growth rates at lower food concentrations than copepodites. This is supported by the empirical evidence of Calbet \& Alcaraz (1997), Camp- 
bell et al. (2001) and McKinnon \& Duggan (2003), who found that the critical concentration for maintaining maximum growth rates was greater for copepodites than for nauplii.

The use of these specific equations (Mauchline 1998 for metabolic rate versus size and Peters \& Downing 1984 for clearance rates versus size) imply that the daily metabolic requirements of nauplii and copepodites scale differently to ingestion, and that nauplii ultimately ingest more food per unit respiration than copepodites. Since growth rates and assimilation efficiencies were kept constant in our calculations, the differences in slope between the clearance rate relationship (slope $=0.731$ ) and respiration rate (slope $=0.787$ ) must have resulted in the lower chlorophyll a concentration at which nauplii were food limited. Thus, not only does a copepod's food requirements affect food limitation, but also its capacity to capture and consume food. The strength of the conclusions based on these calculations are highly dependent on the confidence in the slope of the relationships between respiration and grazing rates with body size. Details of the mechanisms of naupliar feeding have been well described (Paffenhöfer \& Lewis 1989, Irigoien et al. 2003, Titelman \& Kiørboe 2003), but it is currently unclear whether nauplii feed more efficiently or more frequently than copepodites. Clearly, there is still much to be learned about the feeding and growth of copepod nauplii and copepodites.

An additional potential explanation for observations that nauplii are less food limited than copepodites and adults is that nauplii respond differently to variations in food concentration than the later stages. Most studies examining food limitation measure growth rates under varying food concentration. However, it is possible that due to the lower levels of lipid reserves of nauplii (Kattner \& Krause 1987) these may not be able to slow their growth and instead, may simply die (Campbell et al. 2001, Hirst et al. 2003).

The results of our study support previous observations that copepod nauplii are less likely to exhibit food limited growth than copepodites of the same species, as we were unable to find relationships between naupliar growth and chlorophyll concentration or light levels. Nauplii, however, have higher metabolic demands per unit weight than the later stages, and thus are expected to be at a disadvantage. We propose that copepod nauplii may compensate for this by either (1) utilising a smaller optimal food resource, which may result in both a more constant food supply and increased assimilation efficiency, (2) having a lower maximum growth rate, and/or (3) ingesting more food per unit respiration. Only the last option appears applicable to the copepods of Passmaquoddy Bay, but the other explanations may be relevant in other sys- tems. Finally, it is also possible that nauplii are often food limited but that, rather than expressing food limitation with a depressed growth rate, they simply die under low food conditions. Only additional studies examining the growth and feeding of copepod nauplii will help us fully understand these relationships.

Acknowledgements. We thank S. M. J. Evans and A. Neuheimer for field and laboratory assistance, R. Gouda for phytoplankton analyses, M. Robertson and R. J. Stafford for carbon analysis of copepod samples, H. Cyr for help with data analyses, and the staff of the HMSC in St. Andrews, New Brunswick, for logistical support and laboratory space. Comments from several anonymous reviewers significantly improved the manuscript. This work was supported by an NSERC operating grant to J.C.R. and an NSERC PGSA and OGS scholarship to K.F.

\section{LITERATURE CITED}

Atkinson A (1996) Subantarctic copepods in an oceanic, low chlorophyll environment: ciliate predation, food selectivity and impact on prey populations. Mar Ecol Prog Ser 130:85-96

Båmstedt U (1986) Chemical composition and energy content. In: Corner EDS, O'Hara SCM (eds) The biological chemistry of marine copepods. Clarendon Press, Oxford, p 1-58

Berggreen U, Hansen B, Kiørboe T (1988) Food size spectra, ingestion and growth of the copepod Acartia tonsa during development: implications for determination of copepod production. Mar Biol 99:341-352

Besiktepe S, Dam HG (2002) Coupling of ingestion and defecation as a function of diet in the calanoid copepod Acartia tonsa. Mar Ecol Prog Ser 229:151-164

Calbet A, Alcaraz M (1997) Growth and survival rates of early developmental stages of Acartia grani in relation to food concentration and fluctuations in food supply. Mar Ecol Prog Ser 147:181-186

Calbet A, Trepat I, Arin L (2000) Naupliar growth versus egg production in the calanoid copepod Centropages typicus. J Plankton Res 22:1393-1402

Campbell RG, Runge JA, Durbin EG (2001) Evidence for food limitation of Calanus finmarchicus production rates on the southern flank of Georges Bank during April 1997. DeepSea Res 48:531-549

Conover RJ (1966) Assimilation of organic matter by zooplankton. Limnol Oceanogr 11:338-345

Dale T, Kaartvedt S (2000) Diel patterns in stage-specific vertical migration of Calanus finmarchicus in habitats with midnight sun. ICES J Mar Sci 57:1800-1818

Davis CS, Alatalo P (1992) Effects of constant and intermittent food supply on life-history parameters in a marine copepod. Limnol Oceanogr 37:1618-1639

Finlay K (2004) Nauplii and copepodites: an evaluation of trophodynamic roles in a north temperate bay-and implications beyond. PhD thesis, University of Guelph, Guelph, Ontario

Finlay K, Roff JC (2004) Radiotracer determination of the diet of calanoid copepod nauplii and copepodites in a temperate estuary. ICES J Mar Sci 61:552-562

Gillooly JF (2000) Effect of body size and temperature on generation time in zooplankton. J Plankton Res 22:241-251 
Hart RC (1990) Copepod post-embryonic durations: pattern, conformity, and predictability. The realities of isochronal and equiproportional development, and trends in the copepodid-naupliar duration ratio. Hydrobiologia 206: 175-206

Head EJH, Harris R (1987) Copepod feeding patterns before and during a spring bloom in Bedford Basin, Nova Scotia. Mar Ecol Prog Ser 40:221-230

Hessen DO, Faerovig PJ, Anderson T (2002) Light, nutrients, and $\mathrm{P}: \mathrm{C}$ ratios in algae: grazer performance related to food quality and quantity. Ecology 83:1886-1898

Hirst AG, Sheader M (1997) Are in situ weight-specific growth rates body-size independent in marine planktonic copepods? A re-analysis of the global syntheses and a new empirical model. Mar Ecol Prog Ser 154:155-165

Hirst AG, Roff JC, Lampitt RS (2003) A synthesis of growth rates in marine epi-pelagic invertebrate zooplankton. Adv Mar Biol 44:14-25

Hirst AG, Peterson WT, Rothery P (2005) Errors in juvenile copepod growth rate estimates are widespread: problems with the moult rate method. Mar Ecol Prog Ser 296: 263-279

Hopcroft RR, Roff JC (1990) Phytoplankton size fractions in a tropical neritic ecosystem near Kingston, Jamaica. J Plankton Res 12:1069-1088

Hopcroft RR, Roff JC (1998) Zooplankton growth rates: the influence of size in nauplii of tropical marine copepods. Mar Biol 132:87-96

Hopcroft RR, Roff JC, Webber MK, Witt JDS (1998) Zooplankton growth rates: the influence of size and resources in tropical marine copepodites. Mar Biol 132:67-77

Huggett JA, Richardson AJ (2000) A review of the biology and ecology of Calanus agulhensis off South Africa. ICES J Mar Sci 57:1834-1849

Huntley ME, Lopez MDG (1992) Temperature-dependent production of marine copepods: a global synthesis. Am Nat 140:201-242

Hygum BH, Rey C, Hansen BW (2000) Growth and development rates of Calanus pacificus nauplii during a diatom spring bloom. Mar Biol 136:1075-1085

Ianora A, Poulet SA, Miralto A (2003) The effects of diatoms on copepod reproduction: a review. Phycologia 42:351-363

Irigoien X, Harris R, Verheye HM, Joly P and 14 others (2002) Copepod hatching success in marine ecosystems with high diatom concentrations. Nature 419:387-389

Irigoien X, Titelman J, Harris R, Harbour D, Castellani C (2003) Feeding of Calanus finmarchicus nauplii in the Irminger Sea. Mar Ecol Prog Ser 262:193-200

Jones RH, Flynn KJ, Anderson TR (2002) Effect of food quality on carbon and nitrogen growth efficiency in the copepod Acartia tonsa. Mar Ecol Prog Ser 235:147-156

Kattner G, Krause M (1987) Changes in lipids during the development of Calanus finmarchicus from copepodid I to adult. Mar Biol 96:511-518

Kimmerer WJ, McKinnon AD (1987) Growth, mortality, and secondary production of the copepod Acartia tranteri in Westernport Bay, Australia. Limnol Oceanogr 32:14-28

Kleppel GS, Davis CS, Carter K (1996) Temperature and copepod growth in the sea: a comment on the temperature-dependent model of Huntley and Lopez. Am Nat 148:397-406

Landry MR (1978) Population dynamics and production of a planktonic marine copepod, Acartia clausii, in a small temperate lagoon on San Juan island, Washington. Int Rev Gesamten Hydrobiol 63:77-119

Mauchline J (1998) The biology of calanoid copepods, Vol 33. Academic Press, San Diego, CA
McKinnon AD, Duggan S (2003) Summer copepod production in subtropical waters adjacent to Australia's north west cape. Mar Biol 143:897-907

McLaren IA (1978) Generation Lengths of some temperate marine copepods: estimation, prediction, and implications. J Fish Res Board Can 35:1330-1341

McLaren IA, Corkett CJ (1981) Temperature-dependent growth and production by a marine copepod. Can J Fish Aquat Sci 38:77-83

McLaren IA, Corkett CJ, Zillioux EJ (1969) Temperature adaptations of copepod eggs from the arctic to the tropics. Biol Bull (Woods Hole) 137:486-493

McLaren IA, Sevigny JM, Corkett CJ (1988) Body sizes, development rates, and genome sizes among Calanus species. Hydrobiologia 167-168:275-284

Merrell JR, Stoecker DK (1998) Differential grazing on protozoan microplankton by developmental stages of the calanoid copepod Eurytemora affinis Poppe. J Plankton Res 20:289-304

Middlebrook K, Roff JC (1986) Comparison of methods for esitmating annual productivity of the copepods Acartia hudsonica and Eurytemora herdmani in Passamaquoddy Bay, NB. Can J Fish Aquat Sci 43:656-664

Murphey JA, Cohen RE (1979) A guide to the developmental stages of common coastal, Georges Bank and Gulf of Maine copepods, laboratory reference no. 78-53. National Marine Fisheries Service, Woods Hole, MA

Omori M, Ikeda T (1984) Methods in marine zooplankton ecology. John Wiley \& Sons, New York

Paffenhöfer GA (1998) Heterotrophic protozoa and small metazoa: feeding rates and prey-consumer interactions. J Plankton Res 20:121-133

Paffenhöfer GA (2002) An assessment of the effects of diatoms on planktonic copepods. Mar Ecol Prog Ser 227:305-310

Paffenhöfer GA, Lewis KD (1989) Feeding behavior of nauplii of the genus Eucalanus (Copepoda, Calanoida). Mar Ecol Prog Ser 57:129-136

Peters RH (1983) The ecological implications of body size. Cambridge University Press, Cambridge

Peters RH, Downing JA (1984) Empirical analysis of zooplankton filtering and feeding rates. Limnol Oceanogr 29: 763-789

Reinfelder JR, Fisher NS (1991) The assimilation of elements ingested by marine copepods. Science 251:794-796

Rey C, Harris R, Irigoien X, Head R, Carlotti F (2001) Influence of algal diet on growth and ingestion of Calanus helgolandicus nauplii. Mar Ecol Prog Ser 216:151-165

Richardson AJ, Verheye HM (1999) Growth rates of copepods in the southern Benguela upwelling system: the interplay between body size and food. Limnol Oceanogr 44:382-392

Roff JC, Hopcroft RR (1986) High precision microcomputer based measuring system for ecological research. Can J Fish Aquat Sci 43:2044-2048

Roff JC, Turner JT, Webber MK, Hopcroft RR (1995) Bacterivory by tropical copepod nauplii: extent and possible significance. Aquat Microb Ecol 9:165-175

Sheldon RW, Prakash A, Sutcliffe WHJ (1972) The size distribution of particles in the ocean. Limnol Oceanogr 17: $327-340$

Stoecker DK, Egloff DA (1987) Predation by Acartia tonsa Dana on planktonic ciliates and rotifers. J Exp Mar Biol Ecol 110:53-68

Strickland JDH, Parsons TR (1968) A practical handbook of seawater analysis. Bull Fish Res Board Can 167:1-311

Titelman J, Kiørboe T (2003) Motility of copepod nauplii and implications for food encounter. Mar Ecol Prog Ser 247: 123-135 
Torres CG, Escribano R (2003) Growth and development of Calanus chilensis nauplii reared under laboratory conditions: testing the effects of temperature and food resources. J Exp Mar Biol Ecol 294:81-99

Touratier F, Legendre L, Vezina A (1999) Model of copepod growth influenced by the food carbon:nitrogen ratio and concentration, under the hypothesis of strict homeostasis. J Plankton Res 21:1111-1132

Turner JT, Roff JC (1993) Trophic levels and trophospecies in marine plankton: lessons from the microbial food web. Mar Microb Food Webs 7:225-248

Turner JT, Tester PA (1992) Zooplankton feeding ecology:

Editorial responsibility: Otto Kinne (Editor-in-Chief), Oldendorf/Luhe, Germany bacterivory by metazoan microzooplankton. J Exp Mar Biol Ecol 160:149-167

Turner JT, Levinsen H, Nielsen TG, Hansen BW (2001) Zooplankton feeding ecology: grazing on phytoplankton and predation on protozoans by copepod and barnacle nauplii in Disko Bay, West Greenland. Mar Ecol Prog Ser 221:209-219

Uitto A (1996) Contribution of nanoprotists to metazooplankton diet in a mesocosm experiment in the coastal northern Baltic. J Plankton Res 18:2119-2137

Utermöhl H (1958) Zur Vervollkommnung der quantitativen Phytoplankton-Methodik. Mitt Int Ver Theor Angew Limnol 9:1-38

Submitted: July 15, 2005; Accepted: November 24, 2005 Proofs received from author(s): April 11, 2006 